水資源・環境研究VOL. 14（DEC. 2001）

水資源・環境研究

Vol.14 Dec.2001

中野 pp.21 27

研究ノ一ト

\title{
水上レクリエーションの水環境に及ほす影響 水上オートバイを例に
}

中野桂

满賀大学絟済学部

要 旨

近年增加の傾向にあるレジャ一用動力船の多くは、2ストロークエンジンを使用しており、べ ンゼン、トルエン、エチルベンゼン、キシレンや、メチルターシャリープルエーテル(MTBE)、 多理芳香族炭化水絮 $(\mathrm{PAH})$ 等の化学物啠を水中に排出するとされる。本稿ではまず、水上オー トバイを例に、これまでの研究について概観および検討した。その結果、改良型の直接喷射式工 ンジンは決定的な排仙㴥诚とはならないか、4 ストロークエンジンはかなり排出を娍らすといか れて扔り、有効であることがかかった。この他の対策としては、走行区域・隻数・時間等の制限、 あるいは動力船の使用禁止が考えられる。消極的な対策としては、飲料水の彼水口付近での航行 を禁止すること、取水口の位置を深くすること、また壏素処理を行っているところではそれを止 めて、オゾン処理等に切り替えることなどが考えられる。最後に、今後望まれる調查ならびに対 策について議諭した。

キーワード：水上レクリエーション、2 ストロークエンジン

\section{I はじめに}

水上レクリエーションのあり方は時代とともに 変遷をしている。以前は、水泳、ヨット、手漕き ボートなどが盛んであったが、近年はクルーザー や水上オートバイ、バスボートなどのプレジャー 用動力船が多数見られるようになった。特に水上 オートバイは、小型であり収納場所に困らず、持 ち運びも简単であること、洒格も従来の大型将一 トとは比較にならないほど安いこと、また1999年 5 月の法改正によって小型 5 級船船操絴上制度が 創設され免許が取得しやすくなったこと、などが あいまって急速に増加している。2000年 3 月現在、 日本全国で103,213台の水上オートバイが登録さ れ、2000年 4 月期には1,124台が新造検査されて いる。これは年間 1 万台以上の增加ペースである”。

動力船に用いられているエンジンを推進機構別 に分類すると、船内機、船内外機、船外機、ジェ ット推進式の 4 つに分類することができる”。それ ぞれの排気方式を見てみると、船内機は空中排気 であるが、そ机以外は空中排気と水中排気を併用
している。すなわち船内外機抢よび船外機では、 アイドリング時では排気逃がし口より空中排気す るが、滑走時は水中排気している。ジェット推進 式ではアイドリング時およで中低速走行時では水 中排気、高速走行時のみ空中排気となっている。

また、燃焼サイクルという観点からは、2 ス卜 ロークエンジンと4ストロークエンジンに分汁るこ とができる。2 ストロークエンジンは構造か簡単で 軽量、小型で高出力が得られる半面、燃料のシリ。 ンダー内人の吸入と排気がほぼ闹時に行われるため に、燃料の一部が末燃焼のまま排出される。カリフ オルニア州環境保全局 (California Environmental Protection Agency)によると、燃料のうち最大 $30 \%$ が末然焼のまま排出され、例えば 2 ストロー クエンジン搭載の水上オートバイが 7 時間走ると 乗用車が 16 万 $\mathrm{km}$ 走ったに等しい排気がスが排出さ れるという3。ままた騒音も大きい。一方、吸入過程 と排䒝過程を分けている4 ストロークエンジン浊、 未燃焼燃料の排出は少なく一般的に騒音も少ない が、構造が複雑で重い。

水上オートバイや多くのプレジャー用動力船は、 
現在までのところ2 ストロークエンジンのジェッ 卜推進式もしくは船外機を使用しており、以下に 詳述するように、ベンゼン、トルエン、エチルベ ンゼン、キシレンや、メチルターシャリーブチル エーテル (MTBE)、多環芳香族炭化水素 $(\mathrm{PAH})$ 等の化学物質を水中に排出するとされ、水環境へ の影響が䀣念されている。本稿では、近年急速に 数が増加し、エンジンの構造ならびにその使用形 態から環境負荷が大きいとされる水上オートバイ を例に、水上レクリエーションの水環境に及ぼす 影響を考察する゙。

\section{IIこれまでの研究ならびに現況}

2 ストロークならびに 4 ストローク船外機の水 質への影響調査はMastran他をはじめとし、1990 年半ば頃から欧米では盛んになされるようになっ てきだ。

Mastranらの研究は、モーターボートの活動す る眝水湖で水と底質について調查を行ったもので ある。彼らによると、ボート活動の集中する 1990 年 6 月に、ピレン、クリセン、ベンゾ $(\mathrm{a})$ アントラ セン、ベンゾ $(\mathrm{a})$ ピレンその他合計11種類のPAH について測定を行ったところ、どのPAHも33ケ 所のいずれかの調查地点から检出されだ。ほとん どのPAHは $3-6$ 割の地点で検出され、PAH合 計濃度は、水深 5-25フィートで最大で $4.12 \mu \mathrm{g} / \ell$ であった。また特に港の表層水を調べたところ、 $18.86 \mu \mathrm{g} / \ell$ のPAH合計濃度を示した。この地点で はナフタリン、アセナフチレン、およびアセナフ

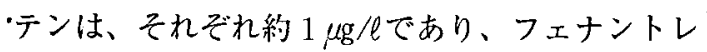
ン、ピレン、クリセン、ベンゾ(a)アントラセン、 およびベンゾ $(\mathrm{a})$ ピレンは、それぞれ $2.3 \mu \mathrm{g} / \mathrm{l}$ 以上 であった。そしてこれらのPAHについて、ボー ト活動の低い10月に、これらの地点で調査したと ころまったく発見されなかったという。米国の連 邦環境保全局 (Environment Protection Agency; EPA)のベンゾ(a)ピレンについての飲料水基集が $0.2 \mu \mathrm{g} / \ell$ であることを考えると、港の表層水は非 常に高い值を示しており、燃焼後の物質だけでな く、未燃焼燃料そのものが混ざっていた可能性が 指摘されている。しかしながらいずれにせよ、ボ 一ト活動と水質污染の関係が明らかになり、その
後、魚や人体に及ほす影響など幅広い調査が進め られることになった。

1999年 5 月、米国の国立公園事務所 (National Park Service) は一連の研究を水上オートバイに 焦点を絞ってまとめ、報告書を出した”。この報告 書は、特に生物および人体へのリスクを包括的に 検討したものであり、水上オートバイの水質への 影響を知る上での重要な文書である。

これに対し日本国内では、1998年から1999年に かけて近譏の水道企業管理者からなる淀川水質協 議会が行った調查が水質調査としては初めてのよ うである。これを受けて1999年に、旧運輸省海事 局船舶安全課を主管として「マリンエンジン排出 ガスの水質影響調査委員会」が調查を行った。こ の調査委員会は「マリンエンジン」と銘打った調 查委員会であるが、実質的には水上オートバイの 水質影響を調查したものである。この調查概要報 告は、過去における欧米の研究について言及して おらず、またその影響調查も、水質のみに限った ものである。

2001年に入って滋賀県内の環境団体が氷上オー トバイの活動水域でMTBEやベンゾ $(\mathrm{a})$ ピレンの 調査を行い、最大 $14 \mu \mathrm{g} / \ell の \mathrm{MTBE}$ 検出した。環 境四体の要請を受けて、滋賀県でも 8 月に独自調 查を行っだ。その結果、水上オートバイの活動水 域内の 8 ケ所のうち 7 ヶ所からMTBEを、そのう ち 3 ヶ所からはベンゼン、トルエン、キシレン、 MTBEのすべてを検出した（検出限界 $1 \mu \mathrm{g} /$ /)。最 大濃度は、ベンゼンからそれぞれ順番に、4、38、 23、 $4 \mu \mathrm{g} / \ell$ であった。一方、ベンゾ(a)ピレンの他、 フルオランテン、クリセン、ベンゾ(e)ピレン、ベ ンゾ $(\mathrm{g}, \mathrm{h}, \mathrm{i})$ ペリレン、ピレン、ベンゾ $(\mathrm{a})$ アン トラセン、ベンゾ $(\mathrm{k})$ フルオランテンについても 検查を行ったが、すべて不検出であった（検出限 界0.05 $\mu \mathrm{g} / \ell$ )。

こうした水上オートバイと水質污染との因果関 係の調查の一方で、排出が疑われている物資の毒 性や水中挙動についての知見も積み重ねられてき た。PAHには、微量でも発がん性や内分泌系摚 乱作用 (いわゆる環境ホルモン作用) があるとさ れるものある”。 PAHのうち水溶性の高いものは 通常の浄化施設では取り除さにくいとされ、浅瀬 
では光化学反応を起こし毒性が増すことや、塩素 処理をすると毒性が増すものもあることがわかっ てきているは，MTBEは、動物において発がん性 の確認された物質で、2002年末までにカルフォル ニア州で販売が禁止になり、日本でも2001年 8 月、 年内に石油元売り大手 4 社が販売を中止すると発 表した ${ }^{11 \%}$

アメリカでは騒音や安全性の観点から1990年代 初頭から地方自治体レベルでの水上オートバイ規 制が始まってきた ${ }^{12)}$ 。動力船と水質污染の関係が 明らかになってきてからは、特に飲料水を供給し ている湖・貯水池を中心に水上オートバイを含む 動力船へのより厳しい規制が行われるようになっ てきた。特に、米国の国立公園事務所は、前述の 1999年の報告書を受けて、2000年に米国ではほと んど全ての国立公園ならびにレクリエーション地 域において水上オートバイ一切禁止という方針を 打ち出している。一方日本では、屈斜路湖 (阿寒 国立公園) や琵琶湖（琵琶湖国定公園）に始まり、 各地のダム湖にいたるまで多くの湖で、環境面で の規制が未だ無いままに利用されているのが現状 である。

\section{III＼cjkstart環境対応型モデルの有効性}

2 ストロークエンジンの排出ガスを減らすため の技術として現在までのところ実用化されている のは、触媒を使った方法と、燃料の直接噴射方式 である。触媒の有効性は早くから指摘されてきた。 ヤマハの開発したシステムでは約45\%を削滅する ことができるという ${ }^{13)}$ 。燃料の直接噴射方式は、メ 一カーによってその方式は若干異なるものの、電 子的にモニターしながら排気プロセスが終わった 後に燃料を燃焼室に直接注入する方式である。こ の方法では、未燃焼燃料が排気として外に出るこ とを防げるため、炭化水素( $\mathrm{HC}$ )や窒素酸化物 (NOx) の排出量を従来型の 2 ストロークエンジンと比較 して約 $75 \%$ 削滅できるといわれる ${ }^{14)}$

しかし直接噴射式であっても、同じ馬力の 4 ス トロークエンジンと比べると、2 2 ストロークエン ジンからの排気は 4 倍多いとされる ${ }^{15)}$ 。したがっ て、水環境保全の視点からは明らかに4ストロー クエンジンが好ましい。こうした事情を背景に、
ホンダ(日本)ならびにボンバルディエ社(カナダ) は 4 ストロークエンジン搭載の水上オートバイを 2001年に開発、発表したが、ホンダについては日 本での発売は未定、ボンバルディエ社については 2002年モデルとして発売の予定となっている16。 以下では、従来型モデルと（直接噴射式と思わ机 る）環境対応型モデルを比較検討したマリンエン ジンの水質影響調查委員会が行った調査の結果に ついて検討してみたい"呢。

マリンエンジンの水質同調查委員会による従来 型と環境対応型の比較は実験室でモデル系を用い て行われた。まず実験の方法であるが、実験には 2 種類の 2 ストローク 3 気筒 $1,200 \mathrm{cc}$ エンジンを 使用した。一種類は徉来型モデル、もう一種類は 日本舟艇工業会が自主的に設置した2006年排出基 準目標を達成した2006年規制值達成モデルと呼ば れるものである。この白主規制は、2006年までの 間に排出ガス含有物を段階的に1998年の75\%まで 減らそうという米国のEPAの規制に準ずるもので、 2006年での目標值は同じである⿸丆口悬体的にどの メーカーのどのモデルが使用されたかは明らかに されていないが、いわゆる直接噴射式といわれる 技術を用いだンジンであると推察される。

テストにはISO 8178-4 E 4 モード法が採用さ れ、スロットル全開 $(\mathrm{M} 1 ; 7200 \mathrm{rpm})$ 、半開 $(\mathrm{M}$ $4 ; 2080 \mathrm{rpm})$ およびアイドリング (M5；1400rpm) の 3 つの時にどの程度の炭化水素化合物 (ベンゼ ン、トルエン、キシレン)が排出されるが調ベられ た。テストに使用された燃料はレギュラーガソリ ンで、vol\%でみたときの含有量はベンゼン $0.7 \%$ 、 トルエン $5.64 \% 、 \mathrm{~m}$ ーキシレシ $3.02 \% 、 \mathrm{p}$-キシレ ン $1.25 \%$ 、および。ーキシレン $1.54 \%$ ある。

結果は以下のように要約できる(表 1 参照)。ア イドリングモード(M5) で、従来型エンジンに比 ベて2006年規制值達成モデルは、ベンゼン、トル エン、およびキシレンの排出を $38.2 \% 、 8.4 \%$ 、お よび10.5\%にそれぞれ減らすことに成功している。 しかし、エンジンが通常多用されるであろう回転 数にあるときは、排出の削減はそれはど大幅では ない。アクセルを少し開いた場合（M4）、2006年 モデルの排出レベルは、従来型のそれぞれ63.7\%、 42.2\%、および11.7\%である。スロットル全開時 
水資源・環境研究VOL. 14（DEC. 2001）

表 1 従来型と環境対応型モデルの比較

\begin{tabular}{|c|c|c|c|c|}
\hline & モード（回転数） & $\begin{array}{c}\text { a 従菜型モデル } \\
(\mathrm{ppm})\end{array}$ & $\begin{array}{c}\text { b 2006年規制值達成 } \\
\text { モデル (ppm) }\end{array}$ & $\begin{array}{l}\text { 排出比 } \\
(\mathrm{b} / \mathrm{a})\end{array}$ \\
\hline \multirow{3}{*}{ ベンゼン } & M5 (1400rpm) & $1,104.73$ & 422.16 & $38.2 \%$ \\
\hline & M 4 (2080rpm) & 106.3 & 67.66 & $63.7 \%$ \\
\hline & M] (7200rpm) & 69.9 & 63.6 & $91.0 \%$ \\
\hline \multirow{3}{*}{ トルエン } & M5 (1 400 rpm) & 2,000 & 168.75 & $8.4 \%$ \\
\hline & M4 (2080 rpm) & 158.16 & 66.8 & $42.2 \%$ \\
\hline & M I (7200rpm) & 156.2 & 192.68 & $123.4 \%$ \\
\hline \multirow{3}{*}{ キシレン } & M5 (1400rpm) & 851.61 & 89.24 & $10.5 \%$ \\
\hline & M 4 (2080rpm) & 191.54 & 22.48 & $11.7 \%$ \\
\hline & M1 (7200rpm) & 134.43 & 73.4 & $54.6 \%$ \\
\hline
\end{tabular}

運輸省海上技術安全局船用工業課「マリンエンジン排出ガスの水質影響調査委員会 検討結果概要」、1999年10月より作成

(M1)では、排出レベルは、それぞれ91\%、123.4\%、 および54.6\%となる。つまり、キシレンについて は約半分になるものの、それ以外についてはわず かに減少するか (ベンゼン)もしくは逆に増加（下 ルエン)してしまっている。

調查はなぜか、汎用回転域と思われる他の中間 的モード（M 2、M 3)でのテストを行っていな いが、それらのモードにおける排出水準はM 1 と M 4 の中間に位置すると想像することができる。 2006年規制值達成モデルは1998年型にくらべ炭化 水素の排出量を $25 \%$ に減らすはずであるが、個令 の化学物質についてみるとばらつきがあることが わかる。

水上オートバイは釣り船等とは違い、スピード やスリルを楽しむ目的に使われることが多い。そ のためにアクセルは全開に近い状態で使われるこ とが多い。また浜でエンジンをかけてすぐ沖合に 乗り出すことが多く、陸上の乗り物のように信号 や啮滞に出くわすこともない。したがって、水上 オートバイの場合、アイドリング状態である時間 は極端に少ないと考えられる。

以上のことから、直接噴射式エンジンはアイド リング時の排出を減らすという意味では効果があ るが、実際の使用状態では、決定的な解決とはな らないことがわかる。また、水上オートバイの大 排気量化が進み、台数の增加も著しい現状を考え ると、直接噴射式エンジンの採用による総排出量 の滅少はあまり期待できないと思われる。

\section{IV 考えうる対策}

水質への影響を減らすためにはいくつかの対策
が考えられる。実際に世界各国でとられている对 策を見ると、湖の使用状況に合わせて、従来型 2 ストロークエンジンを禁止し、直接噴射式もしく は 4 ストロークなどより排出の少ない水上オート バイのみを許可しているケース（例、夕ホ湖、以 下いずれもカリフォルニア州)、一日の走行台数 あるいは時間を制限しているケース（例、コヨー テ湖）、水上オートバイの使用を一切禁止してい るケース (例、キャニオン湖) など様々である。特 に、飲料水用の水源地となっているような湖では、 水上オートバイのみならず全てのエンジンつきボ 一トの使用を禁止しているところが多い翌。

その他にも消極的な対策としては、飲料水の取 水口となる付近でも航行を禁止することである。 ある種のPAHは浅瀬では光化学反応を起こし毒 性が增すことや、塩素処理をすると毒性が増すも のもあることがわかってきているので、取水口の 位置を光の届きにくい樑さにまで移すことや、塩 素処理を行っているところではそれを止めて、才 ゾン処理等に切り替えることも考えられる。

一般に、欧米では全面的禁止を含皦しい対策 が水上オートバイやその他の動力船に対してとら れてきている ${ }^{201}$ 。これに対し、日本各地でも対策 がとられてきているが、法律が整わず「自肃要請」 や「自主規制」にとどまっているところがほとん どである(例、淀川、ならまた湖・奥利根湖、屈 斜路湖)。これは、動力船が水質污染源として認 識されてこなかったことの証であるが、今後河川 法やその他の法律の改正を含めて、法整徣の上で も対策を進めていく必要があろう。 


\section{V これからの課題}

水上オートバイに限らず、水上レクリエーショ ンのもたらす環境問題は、これからますます重要 な課題となってくる。しかしながら研究者の間で はまだ非点源の污染源として十分に認識されてお らず、研究蓄積も少ないようである。例えば琵琶 湖では近年CODは横ばいもしくは長期的には悪 化の傾向があるとされるが、その原因としてこう した水上レクリエーションボートの活動が疑われ たことはこれまでなかったようである゙1)。

まとめに代えて、以下に水質問題に関する課題 をいくつかあげておくことにする。

まず国内ではベンゼン、トルエン、キシレン、 といった揮発性有機物質について主に調査がされ ているが、今後多環芳香族炭化水素についての詳 細な調査が必要であろう。理由は、海外ではかな りの量の多環芳香族炭化水素が検出されているか らである。特に、ラボテストで一台あたりの排出 量を明確にすることが重要である。さらに、底質 についての調查も必要である。水上オートバイと 底質污染の関係は、国内では奏証されていないし、 多環芳香族炭化水素が底質に吸着している可能性 はかなり高い。次に、アイドリングか全開かとい う極端な場合だけでなく、いくつかの中間開度を 含むラボテストを行う必要がある。また、今後 4 ストローク化がますます進むと思われるので、従 来型と直喷式に 4 ストロークエンジンを加えたテ ストも必要となる。できれば触媒式についても検 討すべきである。これらをまとめると、旧運輸省 の検討会が行ったテストを、検出対象物質、スロ ットル開度、エンジンタイプについてより広げ、 さらに底質にまで分析範囲を広げて行う必要があ るということになる。

また水上オートバイのような移動排出源の場合、 従来の水質基準等の環境基準は「基準」としての 機能を果たせなくなってしまうという政策上の問 題がある。排気口から 1 メートルのところで測る のか、10メートルのところで測るのかでは、污染 物質の濃度は著しく異なる。ましてや、その排出 源が不規則移動しているのであり、测定水域の広 さをどの程度とするかによって、水質基準そのも
のを数桁動かしているのと同じことになってしま うからである。残念ながら、研究者や水資源管理 担当者の中にもこの基本的な認識すら持ち合わせ ていない場合がある。政策論の立場からは、紷傎 荷量削隇を中心に据えた指針作りが必要である。

一台の水上オートバイからの排出物を総合した 人体抢よび生態系へのリスクは、これまで考えら れてきた以上に大きなものであることがわかって きた。台数が急速に増加していることもあり、早 急な調查ならびに対策が必要である。本稿では、 水上オートバイの、またさらに水質污染だけに焦 点を絞って検討してきたが、水上レクリエーショ ンの抱える潜在的環境問題は、騒音、安全、湖岸. 海岸環境破壊、生態系への影響、大気污染、など このほかにも多岐にわたる。例えば水上オートバ イで言うと、出艇のために湖岸 (海岸)に車両を 乗り入れ、貴重な湖岸 (海岸) 環境を破壊してい る事例が全国で多数発生している22)。また、生態 系への影瑤としては、水上オートバイの発する音 が水鳥の聞きにくい音域にあるために、直前に近 づいてきてから慌てて飛びたったりすることが多 いとされる。結果として営巣放裹などの事態も起 こっているというう231。わざと水鳥の中へ走りこむ 水上オートバイ利用者の姿が、琵琶湖をはじめい たるところで報告されている。浅瀬を航行すると きの底質の巻き上げによる生態系への影響も賏念 される。これらの点についても専門家による詳細 な調査が望まれるところである。

\section{注}

1) 日本小型船舶検查機棈、『用途別新造』(http: //www.jci.go.jp/toukei/data/Yotosin.SLK) ならびに日本小型船舶検查機構、『検査統計 票』(http://www.jci.go.jp/toukei/kenbetu. $\mathrm{htm})$ 。

2）以下は、運輸省海上技術安全局船用工業課 『マリンエンジン排出ガスの水質影響調查委 員会 検討結果概要』、1999年10月を参考に した。

3) California Environmental Protection Agency, Air Resources Board, "Fact Sheet - 
New regulations for gasoline marine engines", 1999 (http://www.arb.ca.gov/ msprog/marine/marine.htm).

4) 水上オートバイは水上バイクもしくはパーソ ナル・ウォーター・クラフト (Personal Watercraft）と呼ばれる。何をもって水上才 ートバイと定義するかは場合によって異なる が、本稿ではジェット水流を推力とし、主に $1 \sim 3$ 人用のものとしておく。

5) Mastran, R.A.; A.M. Dietrich; D.L. Gallegher; and T.J. Grizzard, "Distribution of polyaromatic hydrocarbons in the water column and sediments of a drinking water reservoir with respect to boating activity" Water Research, 28: p.p. 2353-2366, 1994. Jütner, Friedrich; Diedrich Backhaus; Uwe Matthias; et al., "Emissions of Two- and Four-stroke Outboard Engines -I Quantification of gases and VOC" Water Research, 29:8, pp. 1976-1982, 1995. Jütner, Friedrich; Diedrich Backhaus; Uwe Matthias; et al., "Emissions of Two- and Four-stroke Outboard Engines -II Impact on Water Quality" Water Research, 29:8, pp. 1983-1987, 1995. "Investigation of the Biological Effects of 2-Cycle Outboard Engines' Exhaust on Fish" Marine Environmental Research, 39:1-4, pp. 313316, 1995. Tjänlund, Ulla; Gunilla Ericson; Eric Lindesjöö; et al., "Further Studies of the Effects of Exhaust from Two-Stroke Outboard Motors on Fish" Marine Environmental Research, 42:1-4, pp. 267271, 1996. 最近のものとしては、Mosisch, T. D.; and A. H. Arthington, "Polycyclic aromatic hydrocarbon residues in the sediments of a dune lake as a result of power boating" Lakes and Reservoirs, 6: p.p. 21-32, 2001.

6）最も一般的なPAHは、フェナントレン、ピレ ン、クリセン、ベンゾ(a) アントラセン、ベ ンゾ(a)ピレン、およびアセナフテンであり、
港の表層水からは、上記のものに加え、ナフ タリン、アセナフタリン、アントラセン、フ ルオレン、およびフルオランテンを検出した とされる。

7 ) VanMouwerik, Mark and Hagemann Matt, "Water Quality Concerns Related to Personal Watercraft Usage" Department of the Interior, National Park Service, Water Resources Division, May 27, 1999.

8 ）滋賀県琵琶湖環境部環境政策課、「水上バイ

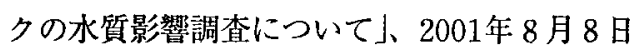
(http://www.pref.shiga.jp/hodo/e-shinbun/ 2001/8/8/0808de0001.PDF)。

9 ）例えば、松沢貞夫、「有害多環芳香族炭化水 素 $(\mathrm{PAH})$ の環境挙動と運命—PAHの発生 源、移動および分解について」NIREニュー ス、資源環境技術総合研究所、2000年11月。

10) Mori, Y.; S. Goto; S. Onodera; et al., "Change in Mutagenic Properties and Chemical Fate of Benz(a)Anthracene in Chlorine-treated Water with and without Bromide Ion" Chemosphere, 27:11, p.p. 21552162, 1993.

11) Calfornia Environmental Protection Agency, “ARB Bans MTBE And Modifies Rules For Cleaner Burning Gasoline" December 9, 1999, Release 99-45 (http://www.arb.ca. gov/newsrel/nr120999.htm）および朝日新聞、 2001年 8 月 6 日。

12）例えば、カリフォルニア州のMendocinoでは 1991年に沿岸部の沼で禁止をした。1999年 4 月28日にJ. C. Bradleyからノースカロライナ 州のSouthern Shores之いう町のTown Council に宛てた「More Effective Regulation of Jet skis」と題するメモ (http://www.nonoise. org/resource/jetskis/jsmemo.htm) 参照。

13）丸山修、「ジェットの環境問題」「How to Jet Style』、ネコ・パブリッシング、p.p. 114-115、 2001年。

14）同上。

15) California Environmental Protection Agency, Air Resources Board, "Fact Sheet - 
New Regulations for 'Gasoline Engines", 1999 (http://www.arb.ca.gov/msprog/marine/ marine.htm).

16）丸山修、「4 サイクルジェットを引き提げて ホンダがジェット業界に殴り込み」『How to Jet Style』、ネコ・パブリッシング、p136な らびにボンバルディエ社のホームページ (http://bombardier-jp.com/) 参照。なお初稿 提出後、ヤマ八も 4 ストロークの水上オート バイを開発との情報得たので付記しておく。

17）前出、「マリンエンジン排出ガスの水質影響 調查委員会 検討結果概要』。

18）日本舟艇工業会ホームページ（http://www. marine-jbia.or.jp/jbi/katsudo.htm)より。ただ し、カリフォルニア州では2001年までに75\%、 2008年までには90\%を削減するという目標を 立てている (前出、California Environmental Protection Agency, Air Resources Board)。
19) California Department of Boating and Waterways, "Local Restrictions on Personal Watercraft and/or Two Stroke Engines" (http://www.dbw.ca.gov/mtbe_list.htm).

20）例えば、1999年のConservancy of South Floridaの報告によると、スイスでは国中の 全ての湖でいかなる使用も制限されている。 The Conservancy of Southwest Florida. "Position Statement, Personal Watercraft," revised, February 22, 1999.

21）国土交通省 河川局河川環境課「平成12年全 国一級河川の水質現況」2001年 7 月26日、 (http://www.mlit.go.jp/kisha/kisha01/05/ 050726_.html)。

22）本栖湖、琵琶湖など。

23）前述のThe Conservancy of Southwest Florida (1999)より。 